\title{
ARCHIWUM MIEJSCEM PAMIĘCI O LUDZIACH NAUKI I KULTURY
}

Abstract

\section{AN ARCHIVE AS A PLACE OF REMEMBRANCE ABOUT THE PEOPLE OF SCIENCE AND CULTURE}

Based on the case study of the Archive of Science of the Polish Academy of Sciences (PAN) and the Polish Academy of Arts and Sciences (PAU) in Cracow, hereinafter referred to as the PAN and PAU Archive of Science, the paper deals with an archive as a place of remembrance about scholars and remembrance management. The article discusses the concept of remembrance in culture and the humanities as well as the concept of a remembrance site in the context of archival studies. The PAN and PAU Archive of Science is presented as a place of remembrance about the people of science and culture on the Cracow's archival and cultural map. In addition, the paper touches upon the subject of scholar's legacy as a means of cherishing their memory based on selected examples from the Archive of Science. The final section presents various forms of activities performed by archivists who manage the memory of the people of science and culture, using the employees of the Archive of Science as an example.

SŁOWA KLUCZE: pamięć, miejsca pamięci, nośniki pamięci, archiwistyka, archiwum, archiwalia, archiwista, zarządzanie pamięcią

KEY WORDS: remembrance, places of remembrance, means of memory cherishing, archival studies, archive, archive records, archivist, remembrance management 


\section{Przemijamy. Stare ustęuje miejsca nowemu, w ten sposób świat posuwa się naprzód. Ale pamiętajmy o tych, którzy odchodza- ta pamięć daje im nieśmiertelność.}

Rafał Kosik

\section{Pamięć}

W ostatnich dziesięcioleciach, głównym pojęciem wielu dziedzin nauki stała się pamięć w różnych znaczeniach ${ }^{1}$. Szczególną uwagę zarówno $\mathrm{w}$ dyskursie publicznym, jak i wśród badaczy wielu humanistycznych dyscyplin naukowych - począwszy od historii, poprzez socjologię, politologię, antropologię aż do psychologii społecznej - wzbudziła pamięć o przeszłości, określana jako pamięć zbiorowa, pamięć społeczna, pamięć historyczna, zbiorowa pamięć historyczna, pamięć kulturowa, świadomość historyczna, historia żywa, tradycja, pamiętanie czy pamięć przeszłości ${ }^{2}$.

Pamięć jest zjawiskiem budzącym duże zainteresowanie współczesnej humanistyki, a jednocześnie trochę podejrzanym. Jak napisał dyrektor Muzeum Historii Polski Robert Kostro we wprowadzeniu do książki pt. Węzły pamięci niepodleglej Polski:

W gronie historyków traktuje się ją niekiedy jako wątpliwej wartości siostrę „,prawdziwej” historii. Patrzymy na nią z zakłopotaniem, chociaż wiemy, że nie można jej tak po prostu usunąć z rodziny. [...] Pamięć może łudzić, stwarzać wiele problemów i zagrożeń, ale większym zagrożeniem jest jej utrata ${ }^{3}$.

$\mathrm{Na}$ temat zjawiska pamięci powstało wiele opracowań oraz artykułów i nie sposób przywołać tu całej złożoności zagadnień związanych z pamięcią․ Pamięć to pojęcie różnie definiowane. Podobnie jak dla historii i kultury, tak i dla pamięci nie ma jednej słusznej definicji, którą można by uznać za powszechnie obowiązującą i wyczerpującą temat. Definicji takich są dziesiątki i każda z nich próbuje uchwycić $\mathrm{z}$ tego obszernego pojęcia inny, zasadniczy wątek. Pamięć utrwalona i przekazywana odgrywa ważną rolę w kulturze.

${ }^{1}$ K. Wóycicki, Zagadnienie historiografii pamięci, https://kazwoy.wordpress.com/mojepublikacje/zagadnienie-historiografii-pamieci/ [odczyt: 10.06.2015].

2 J. Klaś, Muzea historyczne - pomiędzy pamięcia zbiorowa a polityka pamięci historycznej, „Zarządzanie w Kulturze” 2013, t. 14, z. 3, s. 197.

3 R. Kostro, Wprowadzenie [w:] Węzły pamięci niepodległej Polski, Kraków-Warszawa 2014.

${ }^{4}$ A. Gabryś, O badaniu pamięci, „Historyka. Studia metodologiczne” 2005, t. 35, s. 135-149. Wśród zajmujących się problematyką pamięci wymienić należy: Maurice`a Halbwachsa i małżeństwo - Jana i Aleidę Assmann. Na gruncie nauki polskiej badania nad pamięcią prowadzą socjologowie Barbara Szacka i Andrzej Szpociński. Zob. Wobec przeszłości. Pamięć przeszłości jako element kultury współczesnej, A. Szpociński (red.), Warszawa 2005; B. Szacka, Czas przeszły, pamięć, mit, Warszawa 2006; Pamięć zbiorowa i kulturowa. Wspótczesna perspektywa niemiecka, red. M. Saryusz-Wolska (red.), Kraków 2009. 
W potocznym rozumieniu pojęcie pamięci nie nastręcza zbyt wielkich trudności. Pamięć to proces zachodzący w umysłach każdego z nas, polegający na kodowaniu, przechowywaniu i odtwarzaniu informacji dotyczących własnego życia i doświadczeń. Refleksja nad istotą pamięci - szczególnie w wymiarze społeczno-kulturowym - pokazuje, że pamięć nie odnosi się tylko do prostego procesu rejestrowania i zapisu otaczającej nas rzeczywistości. Pamięć stanowi „rodzaj spoiwa i pomostu pomiędzy wydarzeniami przeszłymi a stanem, w którym znajdujemy się obecnie"s. Jak napisał we wprowadzeniu do swojej książki Michael Rothberg „,memory is the past made present” (,pamięć jest to przeszłość uczyniona teraźniejszością” - przeł. B.W.). Ważne jest więc nie tyle zdarzenie z naszej przeszłości jako takie, ile fakt, że jesteśmy przez to zdarzenie w pewien sposób ukształtowani, a także jego oddziaływanie na teraźniejszość. Pamięć to przeszłość obecna we współczesności. Przez pamięć przeszłość żyje tu i teraz. Nauką humanistyczną zajmującą się badaniem przeszłości jest historia. Pamięć i historia to dwa diametralnie różniące się od siebie pojęcia. „Pamięć jest fenomenem wiecznie aktualnym, więzami łączącymi nas z wieczną

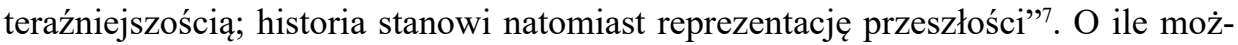
na stwierdzić, że zasadniczym kontekstem dla pamięci jest historia, o tyle nie łatwo jest wyznaczyć owego kontekstu dla pary pojęć historia i pamięć, gdyż oba one przez swoją wieloznaczność wprowadzają nas w sferę interdyscyplinarności. Od początku XXI wieku obserwujemy tendencję do rozwoju odrębnych studiów nad pamięcią i tym samym dystansowania się od bezpośrednich związków także z historią ${ }^{8}$. Niemniej jednak historia jest jedną z form społecznej pamięci przeszłości ${ }^{9}$.

Pamięć to odczuwanie przeszłości, dotykające wszystkich ludzi, „tajemniczy dar wszechobecności w czasie i przestrzeni" ${ }^{\prime 1}$. Pamięć pojedynczego człowieka, czyli pamięć indywidualna, zależna jest w pełni od jednostki i kształtowana przez doświadczenia osobiste. Suma indywidualnych przeżyć i sposobów postrzegania świata wielu jednostek składa się na zjawisko, które francuski filozof i socjolog Maurice Halbwachs określił jako „pamięć zbiorowa”"11. Pamięć zbiorowa jest obrazem prze-

${ }_{5}^{5}$ M. Kuryła, O Instytucie „Pamięci Narodowej”, czyli Polaków problemy z pamięcia oraz historia, http://www.mojeopinie.pl/o_instytucie_pamieci_narodowej_czyli_polakow_problemy_z_pamiecia_oraz_historia,3,1397075661 [odczyt: 10.06.2015].

${ }^{6}$ M. Rothberg, Multidirectional memory. Remembering the Holocaust in the age of decolonization, Stanford 2009, s. 3.

7 P. Nora, Między pamięcia a historią: Les lieux de Mémoire, „Tytuł Roboczy. Archiwum” 2009, nr 2, s. 5.

${ }^{8}$ K. Polasik-Wrzosek, Pamięć kulturowa a historiografia jako zapis kultury. Konteksty do zbadania, „Historyka. Studia metodologiczne” 2011, t. 41, s. 137-138.

${ }_{9}$ K. Pomian, Historia - nauka wobec pamięci, Lublin 2006; J. Le Goff, Historia i pamięć, thum. A. Gronowska, J. Stryjczyk, Warszawa 2007; P. Ricoeur, Pamięć, historia, zapomnienie, thum. J. Margański, Kraków 2007.

${ }^{10}$ E. Bieńkowska, Mała historia pamięci. Pamięć jednostkowa, pamięć zbiorowa, „Znak” 1995, R. 47, nr 480, s. 19.

${ }_{11}$ M. Halbwachs, Społeczne ramy pamięci, tłum. M. Król, Warszawa 1969; F. Pazderski, Czemu przeszłość się pamięta - wokół dyskusji na temat kształtowania się pamięci zbiorowej, http://www.drumla.org.pl/czytelnia.html [odczyt: 10.06.2015]. 
szłości wypracowanym przez większą społeczność, która decyduje, o czym warto pamiętać i w jaki sposób pamięć tę praktykować. Pamięć poszczególnych członków zbiorowości jest podstawowym warunkiem istnienia pamięci zbiorowej, społecznej, określanej jako: istniejący w zbiorowości zespół wyobrażeń o przeszłości tej zbiorowości, a także wszystkie postaci i wydarzenia z tej przeszłości, których znajomość uważana jest za obowiązkową i które są w najróżniejszy sposób upamiętniane, a wreszcie rozmaite formy tego upamiętniania ${ }^{12}$.

Historia jest jedną z form społecznej pamięci przeszłości, a pamięć to także świadomość historyczna ${ }^{13}$. Pamięć jednostki (pojedynczego człowieka) i pamięć zbiorowa, w tym historia, stanowią interaktywną wspólnotę ${ }^{14}$. Historię i pamięć, czy też świadomość historyczną posiadają nie tylko jednostki, ale i społeczności. Na pojęcie świadomości historycznej składa się pamięć przeszłości, która kształtuje się poprzez przekazywanie wiedzy o sprawach z przeszłości przez generacje ustępujące nowym pokoleniom wchodzącym w życie ${ }^{15}$. Świadomość historyczna obejmuje nie tylko pamięć dawnych wydarzeń, lecz także sposób oceniania, wartościowania i włączania przeszłości do teraźniejszości poprzez działania ją upamiętniające. Im bardziej wyobrażenia o przeszłości oparte są na naukowych źródłach historycznych, tym większa jest świadomość historyczna danej społeczności. Świadome budowanie i utrzymywanie wiedzy o przeszłości, a zatem pielęgnowanie pamięci o czasach i ludziach minionych epok to zadanie dla historyków i archiwistów. To właśnie oni, strażnicy pamięci, pielęgnując przeszłość, tworzą przyszłość, gdyż pamięć o przeszłości oznacza zaangażowanie w przyszłość ${ }^{16}$. Wiedza historyczna, popularyzowana i upowszechniana, tworzy szeroko rozumianą pamięć społeczną ${ }^{17}$.

\section{Pamięć w archiwistyce}

Współczesna kultura charakteryzuje się pewnego rodzaju nielogicznością. Z jednej strony nasycona jest produktami przeznaczonymi do szybkiej konsumpcji, cechuje ją tymczasowość i relatywizm, które sprzyjają wykorzenieniu z miejsca i czasu,

12 B. Szacka, O pamięci społecznej, „Znak” 1995, R. 47, nr 480, s. 68.

${ }_{13}$ M. Hlebionek, O pamięci historycznej, http://wirtualnemuzeumtrzcianki.trz.pl/sites/default/ files/Pamięć4.pdf [odczyt: 10.06.2015]; J.A. Jerochina, Pamięć $i$ wiedza o przeszłości jako formy bytowania świadomości historycznej, „Sensus Historiae” 2013, vol. 11, nr 2, s. 63-70.

${ }_{14}$ M. Kurkowska, Archiwa pamięci - oral history, „Historyka. Studia metodologiczne” 1998, t. 28 , s. 67.

15 J. Filipowicz, Pojęcie pamięci społecznej w nauce polskiej, „Kultura i Historia” 2002, nr 2, http://www.kulturaihistoria.umcs.lublin.pl/archives/145 [odczyt: 10.06.2015].

${ }^{16}$ Pamięć dla przyszłości, Z. Stachowski (red.), Tyczyn 2002; B. Korzeniowski, O sposobach obchodzenia się z reliktami przeszłości, „Sensus Historiae” 2012, vol. 6, nr 1, s. 35-47.

17 Wynika stąd, że pamięć może być zarówno podmiotem badań historyka, jak i przedmiotem (narzędziem) w jego warsztacie. Zob. A. Gabryś, O badaniu pamięci, „Historyka. Studia metodologiczne" 2005, t. 35, s. 141. 
a z drugiej - jest „czasem pamięci”" ${ }^{18}$, w którym pamiętanie i upamiętnianie stało się wręcz modne. Funkcjonujemy w kulturze posługującej się „krótkim czasem”, czasem teraźniejszości, pojmowanej jako seria następujących po sobie niepowiązanych momentów, a jednocześnie najbardziej zarchiwizowanej ${ }^{19}$.

Nowoczesna pamięć jest przede wszystkim pamięcią archiwalną. W całości opiera się na materialności śladów, bezpośredniości danych, widzialności obrazu. [...] W im mniejszym stopniu pamięć jest przeżywana wewnętrznie, tym bardziej jej istnienie zależy od zewnętrznych mediów i widocznych znaków - stąd bierze się dotykająca naszą epokę obsesja archiwum, która pragnie jednocześnie całkowitej konserwacji teraźniejszości i absolutnego ocalenia przeszłości ${ }^{20}$.

Francuski historyk, Pierre Nora, tłumacząc to zjawisko zauważa, że

[...] czujemy się zobowiązani do wytrwałego kolekcjonowania pozostałości, świadectw, dokumentów, obrazów, pogłosek, jakichkolwiek widzialnych znaków tego, co było, tak jakby to pęczniejące dossier miało być wykorzystane jako dowód przed nieznanym jeszcze trybunałem historii ${ }^{21}$.

Według Nory, współczesnego człowieka ogarnęła potrzeba pamiętania i niechęć pozbywania się różnych artefaktów przeszłości.

Imperatywem naszej epoki jest nie tylko zachowywanie wszystkiego, ocalanie każdej oznaki pamięci - nawet jeśli nie jesteśmy pewni, jakiego rodzaju pamięć oznaczamy - ale również tworzenie archiwów ${ }^{22}$.

Istotne miejsce $\mathrm{w}$ różnorodnych badaniach nad złożonym i wieloaspektowym zjawiskiem pamięci, odgrywają tzw. miejsca pamięci ${ }^{23}$. Literatura na temat „miejsc pamięci” jest bardzo obszerna, a wyjaśnienia tego pojęcia są nieco odmienne w poszczególnych kręgach kulturowych. P. Nora, prekursor badań nad „miejscami pamięci”, za takie uważa wszystkie

[...] symbolicznie obiekty pamięci: archiwa i zarazem trójkolorowy sztandar, biblioteki, słowniki, muzea i pamiątki, uroczystości, Panteon, Łuk Tryumfalny; Dictionnaire Larousse oraz „ścianę komunardów”, gdzie zginęli ostatni obrońcy Komuny Paryskiej w 1870 roku².

18 P. Nora, Czas pamięci, „Res Publica Nowa” 2001, R. 14, nr 7, s. 37-43.

19 A. Szpociński, Miejsca pamięci (lieux de mémoire), „Teksty Drugie” 2008, nr 4, s. 18; K. Majchrzak, Od miejsc pamięci narodowej do miejsc żywej pamięci-implikacje dla andragogiki, „Rocznik Andragogiczny" 2013, R. 20, s. 302.

${ }^{20}$ P. Nora, Między pamięcia a historia..., s. 7.

${ }_{21}$ Tamże; P. Nora, Between Memory and History: Les Lieux de Mémoire, „Representations” 1989, nr 26, Special Issue: Memory and Counter-Memory, s. 7-24.

${ }^{22}$ P. Nora, Między pamięcia a historia..., s. 7.

${ }^{23}$ A. Szpociński, „Miejsca pamięci” w ujęciu Pierre'a Nory, „Borussia. Kultura, Literatura, Historia” 2003, R. 13, nr 29, s. 16-27; A. Szpociński, Nośniki pamięci, miejsca pamięci, „Sensus Historiae" 2014, vol. 17, $\mathrm{nr}$ 4, s. 17-26.

${ }^{24}$ P. Nora, Między pamięcia a historia..., s. 6. 
W ujęciu Nory miejsca pamięci powstają dzięki interakcji między pamięcią a historią. Celem istnienia i powoływania do życia miejsc pamięci jest ,zatrzymanie czasu, zablokowanie procesu zapominania, ustanowienie pewnego stanu rzeczy, unieśmiertelnienie czegoś martwego, materializacja czegoś niematerialnego"25. Miejsca pamięci są w stanie przekazać maksimum znaczenia przy wykorzystaniu minimalnej liczby znaków. Posiadają zdolność metamorfozy, permanentnego odradzania swego znaczenia i nieprzewidywalną ilość interpretacji ${ }^{26}$. Miejsca pamięci jako „depozytariusze przeszłości”27 mogą być rozumiane zarówno fizycznie - przestrzennie (budowle, cmentarze, place itp.), jak i metaforycznie - jako jakiekolwiek znaki i symbole (postaci, daty, fotografie, piosenki itp.) ${ }^{28}$.

Do takich miejsc pamięci należą archiwa, tworzone po to, by zatrzymać proces zapominania, aby historia zachowała łączność z pamięcią zbiorową. Każde archiwum (państwowe, kościelne, bieżące, czyli zakładowe, społeczne, prywatne) jest miejscem pamięci, bowiem jako instytucja przechowująca materiały archiwalne pozwala w te materiały wejrzeć, a tym samym poznać przeszłość w nich zapisaną 29 . Wychodząc naprzeciw różnym potrzebom i oczekiwaniom publicznym, archiwa w miarę upływu czasu zmieniły swój wizerunek. Powszechnie uznawane jako miejsca pamięci, są one:

[...] wielką skarbnicą narodowej przeszłości, a zarazem zbiorem tytułów prawnych państwa i narodu polskiego, dokumentujących nasze miejsce na mapie politycznej Europy, świadectwem tysiącletniego dorobku cywilizacyjnego i kulturowego, a także działalności władz państwowych i samorządowych, różnych instytucji oraz osób wybitnych i zasłużonych ${ }^{30}$.

Upowszechniająca się coraz bardziej nowa interpretacja działalności archiwalnej polega na budowaniu i szerzeniu pamięci społecznej na podstawie zasobu archiwalnego.

Fenomen pamięci zagościł w refleksji archiwistycznej na przełomie XX i XXI wieku, nadając działalności archiwalnej nowy, głębszy i wznioślejszy wymiar. Pod koniec XX wieku zmieniła się percepcja zarówno archiwów, jak i archiwistów. Archiwistyka jako dyscyplina naukowa rozwijała się długo w powiązaniu $\mathrm{z}$ historią, stanowiąc jej naukę pomocniczą. Praktyczna działalność archiwalna zwrócona była do XX wieku głównie w kierunku zasobu wytworzonego w minionych epokach i wymagała od archiwistów przede wszystkim dobrego przygotowania historycznego oraz umiejętności z zakresu nauk pomocniczych historii. Pod koniec ubiegłego stulecia uległy rozszerzeniu funkcje archiwów. Jak zauważono na XV Międzynarodowym Kongresie Archiwów w Wiedniu w 2004 roku:

25 Tamże, s. 10.

26 Tamże.

27 A. Szpociński, Miejsca pamięci..., s. 15.

${ }^{28}$ K. Majchrzak, Od miejsc pamięci narodowej do miejsc żywej pamięci-implikacje dla andragogiki, ,Rocznik Andragogiczny” 2013, R. 20, s. 307.

29 M. Wiśniewska, Archiwum jako miejsce pamięci, „Archiwa - Kancelarie - Zbiory” 2013, nr 4, s. 137-148.

${ }_{30}$ Zagrożenie archiwów - skarbnicy pamięci państwa i narodu, „Archeion” 1996, t. 96, s. 65. 
Zmieniło się postrzeganie roli archiwów i archiwistów. Archiwa widziane są teraz nie jako składnice dokumentacji, ale miejsca pamięci i jej skarbnice. Archiwiści w związku z tym aktywnie zarządzają pamięcią. Poprzez ocenę wartości dokumentacji, opis archiwaliów, dbałość o ich zachowanie archiwiści wciąż na nowo formują zasób archiwalny. Zyskują ogromną władzę nad pamięcią i tożsamością społeczeństwa ${ }^{31}$.

Niezależnie od definicji archiwum przyjmowanej przez słowniki archiwalne ${ }^{32}$, archiwa przez stulecia były

[...] instytucjami kultywującymi pamięć, świątyniami przeszłości, miejscem w którym przechowywano bezcenne pamiątki kultury, wytwory ludzkiej myśli, dowody narodzin i rozwoju cywilizacji, ludzkich dróg ewolucji religii i kształtowania się wspólnot religijnych, ślady rozwoju gospodarczego, przemian politycznych. Archiwa są osobliwymi pomnikami dziejów. Archiwum to gmach, to budynek, a w nim pomieszczenia, w których znajduje się bezcenna zawartość zwana zasobem, czyli archiwalia mierzone metrami bieżącymi, liczbą jednostek archiwalnych, zespołów, kolekcji, liczbą dyplomów, pieczęci. Archiwum to także jego kustosz, archiwariusz, pracownik archiwum, archiwista, swoisty typ historyka, człowiek-katalog, a ponadto znawca dawnych języków, pisma, kancelarii, urzędów, godności, tytułów, nazwisk, herbów, genealogii ${ }^{33}$.

Pojawienie się w historii polskich archiwów idei wieczystego archiwizowania łączy się z ideą kreowania pamięci. Z kulturoznawczego punktu widzenia potrzeba zaspokojenia pamięci jako motyw gromadzenia i przechowywania archiwaliów pojawiła się w Polsce w XVI i XVII wieku. Wtedy to archiwum stanowiło narzędzie budowania prestiżu rodu poprzez oparcie go na dawności tego rodu oraz rodzinnej tradycji. Działo się to przez zachowywanie dokumentów, które nie miały już znaczenia praktycznego, a jedynie swoją rangą i wiekiem dodawały rodowi splendoru. W wieku XVIII nastąpiło w Polsce „usamodzielnienie się motywu pamięci

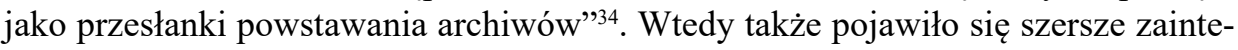
resowanie historią, przejawiające się m.in. w odkrywaniu spuścizn przodków i tworzeniu archiwów rodowych, co jak można przypuszczać było formą zaspokajania potrzeby pamięci. Zaczęto postrzegać archiwa jako skarbnice pamięci narodowej i symbol trwałości państwa. W okresie zaborów archiwa zostały wciągnięte w służbę sprawy narodowej i miały kształtować świadomość narodową Polaków. Pamięć

${ }^{31}$ W. Chorążyczewski, Archiwa i pamięć. Nowa interpretacja archiwistyki (na marginesie XV Kongresu Archiwów w Wiedniu), „Archiwista Polski” 2004, R. 9, nr 4, s. 9.

32 Archiwum - instytucja o charakterze urzędu administracyjnego, urzędu wiary publicznej oraz placówki naukowej powołana do kształtowania, zabezpieczania, gromadzenia, opracowywania oraz trwałego przechowywania i udostępniania materiałów archiwalnych, uprawniona do wydawania z nich uwierzytelnionych odpisów, wypisów, wyciągów i kopii, a także do publikowania źródeł i pomocy archiwalnych oraz prowadzenia badań w dziedzinie archiwistyki. Zob. Polski słownik archiwalny, W. Maciejewska (red.), Warszawa 1974, s. 19.

${ }_{33}$ Zatroskani o ślady przeszłości. Archiwista kościelny we współczesnej rzeczywistości, J. Marecki, L. Rotter (red.), Kraków 2005, s. 5.

${ }^{34}$ W. Chorążyczewski, Archiwa i pamięć. Z dziejów polskich archiwów, „Archiwa - Kancelarie - Zbiory" 2005, t. 1, s. 20. 
zachowana w archiwach miała krzepić serca i podbudowywać morale, zaś archiwalia miały strzec tożsamości narodu przez przypominanie o jego wielkiej przeszłości ${ }^{35}$.

Pomimo iż historia i pamięć stoją do siebie w opozycji, to ani historia, ani pamięć nie mogą bez siebie istnieć. Pamięć to coś, co było, a więc przeszłość, przeszłość to historia. Pamięć i historia wzajemnie się uzupełniają. Historia i pamięć, stykają się z dziedziną archiwistyki, nauką pomocniczą historii, której przedmiotem są archiwa i archiwalia. Kulturoznawcy połączyli archiwistykę i pamięć, określając archiwum jako instytucję pamięci, zaś archiwistów jako osoby zarządzające pamięcią, które w swojej pracy bezpośrednio obcują z archiwaliami, czyli nośnikami pamięci ${ }^{36}$. Z kulturoznawczego punktu widzenia archiwa mają zaspokajać potrzebę pamięci, zadbać o to, by pamięć nie zaginęła, i zabiegać o to, aby pamięć w postaci źródeł historycznych była dostępna dla szerokiego grona odbiorców ${ }^{37}$. Spuścizna zgromadzona w archiwach to wartość, którą archiwiści pragną posiadać i zachować, uchronić przed zniszczeniem i ocalić od zapomnienia, oraz znak, który służąc do komunikacji, ma sens jedynie jako udostępniony ${ }^{38}$. Spojrzenie na archiwistykę z perspektywy problematyki pamięci skłania do refleksji nad relacjami między archiwami i archiwaliami, archiwami i archiwistami oraz archiwami i ich użytkownikami ${ }^{39}$.

\section{Archiwum Nauki PAN i PAU miejscem pamięci}

Według definicji ze Słownika filozofii, pięcioma elementami pamięci są: utrwalanie wspomnień, przechowywanie ich, przypominanie, rozpoznanie, lokalizacja ${ }^{40}$. Te elementy pamięci charakteryzują również archiwa - miejsca pamięci (lokalizacja), w których przeszłość i pamięć nie są wyłącznie deponowane, ale ich ślady są organizowane i kategoryzowane według określonych zasad. Aspekt „,pamięciowy” w archiwistyce przejawia się w postaci gromadzenia (przechowywania), opracowywania (rozpoznawania), udostępniania (utrwalania) i popularyzowania (przypominania) zasobu archiwalnego. Istnienie w określonym regionie takich instytucji jak archiwa stanowi oparcie dla rozwoju życia naukowo-kulturalnego i oddziałuje na poziom lokalnego społeczeństwa. Dla bardziej wprawionej części lokalnej społeczności świadomość, że znajdują się w tych instytucjach źródła świadczące o przeszłości, ma duże znaczenie. Udostępnianie zaś archiwaliów szerszym kręgom i popularyzowanie

35 Tamże, s. 13-28.

${ }^{36}$ O nośnikach pamięci jako wszelkich przedmiotach i działaniach, które mogą stymulować jakiekolwiek wyobrażenia, myśli i wspomnienia przeszłości zob. M. Kula, Nośniki pamięci historycznej, Warszawa 2002; A. Szpociński, Nośniki pamięci..., s. 18-24.

${ }^{37}$ A. Rosa, Archiwa między historia i pamięcia. Antropologizowanie archiwistyki, „ArchiwaKancelarie - Zbiory" 2008, t. 2, s. 105-107.

${ }^{38}$ M. Napiórkowski, Prawda archiwów, „Kultura Współczesna” 2011, nr 4, s. 19.

39 Por. A. Kędziora, Miejsca pamięci w zarządzaniu pamięcia o artyście, „Zarządzanie w Kulturze" 2012, t. 13, z. 2, s. 101-111; A. Kędziora, Zarządzanie pamięcia o artyście na przykładzie szlaku kulturowego, „Problemy Zarządzania” 2013, vol. 11, nr 4, s. 101-112.

40 J. Didier, Słownik filozofii, Kraków 1992, s. 242. 
ich niewątpliwie wpływa na świadomość historyczną i szerzy to, co nazywamy kulturą historyczną. Zasób archiwalny tworzy nie tylko określoną część dziedzictwa kulturowego danego narodu, ale razem z nim część ogólnego dziedzictwa całej ludzkości, którego strzec jest zobowiązane każde państwo ${ }^{41}$. Wartość zasobów archiwalnych, ich różnorodność i walory poznawcze stanowią najważniejszą część polskiego narodowego dziedzictwa kulturalnego ${ }^{42}$. Działalność archiwów polega na budowaniu i szerzeniu pamięci społecznej na podstawie zasobu archiwalnego. To archiwa zapewniają, że nie zaginie pamięć o społeczności jako całości, a także o ludziach w jej działania zaangażowanych.

Każdy z tych ludzi „pojedynczych” ma prawo do uczestnictwa w „pamięci zbiorowej”, prawo do bycia zapisanym w archiwaliach, trwających pod wierną strażą archiwistów $[\ldots]^{43}$.

Zasób archiwalny kształtowany jest w odpowiedzi na społeczną potrzebę pamięci, ,zrzucając na archiwum odpowiedzialność za pamiętanie, zrzucamy tam swoje znaki, tak jak wąż zrzuca swą skórę"44. Gromadzenie, opracowywanie, udostępnianie i popularyzacja materiałów obrazujących osiągnięcia ludzi nauki i kultury to zadanie archiwów posiadających w swoich zasobach spuścizny uczonych i twórców. Do takich miejsc należy Archiwum Nauki Polskiej Akademii Nauk i Polskiej Akademii Umiejętności w Krakowie.

Archiwum Nauki Polskiej Akademii Nauk i Polskiej Akademii Umiejętności jest sprofilowanym archiwum naukowym, którego cel statutowy stanowi: gromadzenie, opracowywanie, udostępnianie oraz publikacja źródeł do historii nauki i kultury. W obecnym kształcie organizacyjnym Archiwum Nauki PAN i PAU rozpoczęło działalność 1 kwietnia 2002 roku w wyniku porozumienia zawartego pomiędzy Polską Akademią Nauk (PAN) i Polską Akademią Umiejętności (PAU) ${ }^{45}$. Archiwum Nauki nie jest instytucją budowaną od podstaw. Swoimi korzeniami sięga XIX wieku i związane jest z dziejami Towarzystwa Naukowego Krakowskiego (TNK)

${ }^{41}$ A. Tomczak, Archiwistyka i zawód archiwisty. Kilka refleksji [w:] D. Nałęcz (red.), Archiwa polskie wobec wyzwań XXI wieku. Pamiętnik III Powszechnego Zjazdu Archiwistów Polskich, Toruń 2-4 września 1997, t. 1, Radom 1997, s. 24.

${ }^{42}$ W. Stępniak, Archiwa - państwo - naród. Dwieście lat na straży pamięci narodowej, „Archiwista Polski” 2008, R. 13, nr 4, s. 21-25; M.W. Mróz, Archiwum jako instytucja kultury historycznej, http://archiwum.amu.edu.pl/publikacje/2.pdf [odczyt: 10.06.2015].

${ }^{43}$ W. Chorążyczewski, Archiwa i pamięć. Nowa interpretacja..., s. 10.

${ }^{44}$ P. Nora, Między pamięcia a historią..., s. 7.

45 Wskutek wieloletnich pertraktacji pomiędzy Polską Akademią Umiejętności i Polską Akademią Nauk, za aprobatą Naczelnego Dyrektora Archiwów Państwowych utworzono w kwietniu 2002 r. Archiwum Nauki PAN i PAU w Krakowie na podstawie zasobu Oddziału PAN w Krakowie i reaktywowanego Archiwum PAU. Tym samym urzeczywistniała się idea rodząca się od dłuższego czasu w Krakowie - powołania specjalistycznego archiwum, gromadzącego materiały archiwalne do dziejów nauki. Utworzone zostało na mocy decyzji Nr 2/2002 Prezesa Polskiej Akademii Nauk z dnia 28 marca 2002 r. Zob. R. Majkowska, Archiwum Nauki-idea i rzeczywistość [w:] Archiwa polskie wobec wyzwań XXI wieku. Pamiętnik III Powszechnego Zjazdu Archiwistów Polskich, Toruń 2-4 września 1997, Warszawa 1998, t. II, s. 177-185; T. Filip, Od archiwum dwóch Akademii do Archiwum Nauki, http://archiwum.amu.edu.pl/publikacje/15.pdf [odczyt: 10.06.2015]. 
powstałego w 1815 roku, przekształconego w roku 1872 w Akademię Umiejętności (od 1918 roku pod nazwą Polska Akademia Umiejętności $)^{46}$, oraz powstałego w 1953 roku Archiwum Polskiej Akademii Nauk ${ }^{47}$. Nadzór nad działalnością tej instytucji sprawuje z upoważnienia Prezesa PAN - Prezes Oddziału PAN w Krakowie.

Archiwum Nauki PAN i PAU mieści się w Krakowie w zabytkowej kamienicy stanowiącej własność Polskiej Akademii Umiejętności przy ulicy św. Jana 26. W miejscu gdzie wznosi się kamienica do połowy XVII wieku była słodownia, później zaczęto tę posesję nazywać domem Dziboniego, od nazwiska Włocha Baltazara Giobbio, który dostarczał królowi Janowi Kazimierzowi armaty na kampanię berestecką. W 1933 roku sekretarz generalny Polskiej Akademii Umiejętności, prof. Stanisław Kutrzeba, dzięki funduszowi zapisanemu Akademii przez Felicję Nemetzową, zakupił tę kamienicę dla PAU. Bieżące informacje o działalności archiwum są zamieszczone na stronie internetowej: www.archiwum-nauki.krakow.pl.

Zasób Archiwum Nauki PAN i PAU stanowią materiały archiwalne należące do państwowego zasobu archiwalnego (zgodnie z dokumentem powierzenia $\mathrm{z}$ dnia 6 marca 2002 r. wydanego Polskiej Akademii Nauk przez Naczelnego Dyrektora Archiwów Państwowych) oraz należące do niepaństwowego zasobu archiwalnego, stanowiące własność Polskiej Akademii Umiejętności. Zasób archiwalny podzielony jest na trzy działy. Pierwszy stanowią akta Towarzystwa Naukowego Krakowskiego (1815-1872), Akademii Umiejętności (1872-1918) i Polskiej Akademii Umiejętności (od 1918 roku) oraz innych towarzystw i instytucji naukowych. W drugim dziale znajdują się materiały archiwalne instytutów, zakładów, placówek i Oddziału Polskiej Akademii Nauk w Krakowie (od roku 1953). Trzeci dział to spuścizny, czyli archiwa osobiste ludzi nauki i kultury (ponad 250 zespołów archiwalnych) ${ }^{48}$.

Archiwum Nauki przejmuje materiały archiwalne z placówek PAN i z PAU oraz pozyskuje spuścizny, a także akta towarzystw naukowych zgodnie z profilem gromadzenia. Jedną z form aktywności Archiwum Nauki jest opieka nad narastającym zasobem PAN i PAU. Archiwum Nauki udziela placówkom PAN oraz PAU konsultacji w sprawach kancelaryjno-archiwalnych, przeprowadza kontrole wewnętrzne i ekspertyzy w archiwach zakładowych Instytutów PAN w Krakowie oraz w krakowskich placówkach warszawskich instytutów PAN. Opiniuje projekty normatywów kancelaryjnych i archiwalnych, a także wnioski o brakowanie akt jednostek organizacyjnych PAN w Krakowie.

${ }^{46}$ O historii zasobu archiwalnego Towarzystwa Naukowego Krakowskiego, Akademii Umiejętności i Polskiej Akademii Umiejętności zob. R. Majkowska, Archiwum Polskiej Akademii Umiejętności-dzieje, zasób, stan opracowania, „Krakowski Rocznik Archiwalny” 1996, t. 2, s. 70-84.

${ }^{47}$ E. Dziurzyńska, Powstanie Archiwum Nauki Polskiej Akademii Nauk i Polskiej Akademii Umiejętności w Krakowie, „Krakowski Rocznik Archiwalny” 2003, t. 9, s. 285-287; T. Skrzyński, Archiwum Nauki Polskiej Akademii Nauk i Polskiej Akademii Umiejętności. Z przeszłości i teraźniejszości, „Archiwista Polski” 2004, R. 9, nr 1, s. 17-20; T. Skrzyński, Archiwum Nauki Polskiej Akademii Nauk i Polskiej Akademii Umiejętności. Z przeszłości i teraźniejszości, Kraków 2008, s. 3-8.

${ }^{48}$ Archiwum osobiste to całość materiałów archiwalnych wytworzonych i zgromadzonych przez człowieka w czasie jego życia i działalności (w tym kolekcjonerskiej), wraz archiwaliami odziedziczonymi. 
Archiwum Nauki systematycznie opracowuje i zabezpiecza zbiory archiwalne. Archiwalia, których udostępnianie jest utrudnione lub niemożliwe z powodu postępującego niszczenia, poddawane są konserwacji.

W Archiwum Nauki przechowywane są dwa specjalistyczne księgozbiory. Biblioteka Rozdolska Lanckorońskich, ofiarowana Polskiej Akademii Umiejętności przez prof. Karolinę Lanckorońską w 1997 roku, a przechowywana i udostępniana w Archiwum Nauki PAN i PAU. Ten liczący około 3000 woluminów księgozbiór zawiera polonika krajowe i zagraniczne, m.in. unikatowe kalendarze staropolskie z końca XVII i połowy XVIII wieku, broszury polityczne siedemnasto- i osiemnastowieczne, a także zbiór konstytucji, ustaw i przywilejów z okresu XVI-XVIII. W Bibliotece Rozdolskiej znaleźć można ponadto publikacje z zakresu historii Polski, historii sztuki, literatury i kultury oraz obszerny zbiór wydawnictw źródłowych. Cenną pomoc dla korzystających z archiwaliów stanowią wydawnictwa źródłowe, biograficzne, słownikowe, encyklopedyczne oraz publikacje naukowe, zgromadzone w specjalistycznej bibliotece historyka nauki i kultury prof. Henryka Barycza, uzupełniającej księgozbiór podręczny archiwum.

Archiwum Nauki PAN i PAU jest miejscem pamięci rozumianym zarówno fizycznie jako budynek - siedziba Archiwum, jak i metaforycznie, jako skarbnica spuścizn - nośników pamięci o ludziach nauki i kultury. Jest miejscem, w którym pamięta się o życiu i działalności polskich uczonych. Akcentuje to stwierdzenie profesora Piotra Hübnera, że „więź z przeszłością musi wynikać - jeśli ma być żywa i bezpośrednia $-\mathrm{z}$ kontaktu z oryginałem: słowem czy obrazem"49. Miejscem, w którym „przeszłość (która dziś nie istnieje, choć kiedyś naprawdę się zdarzyła; której nie można ocalić, choć można ją przedstawić) pozostawiła jakieś ślady i fragmenty, zwykle w formie pisemnej" ${ }^{50}$, jest Archiwum Nauki. To sprofilowane archiwum naukowe gromadzi, opracowuje, udostępnia oraz popularyzuje spuścizny polskich uczonych i badaczy. Gromadząc spuścizny - nośniki pamięci - gromadzi pamięć, zaś archiwiści, opracowując, udostępniając i popularyzując materiały w nich zawarte, tę pamięć udostępniają i popularyzują, zarządzając pamięcią.

\section{Spuścizny nośnikami pamięci}

Idea zachowywania i zbierania materiałów prywatnych, w tym archiwów osobistych i rodzinnych, ma swoją tradycję i długą historię. $Z$ tej idei rodziły się zamysły tworzenia archiwów rodowych, stąd też pojawiła się myśl i decyzja przekazywania do zbiorów instytucjonalnych materiałów po wielkich i znanych postaciach. Tak

49 P. Hübner, Od Towarzystwa Naukowego Krakowskiego do Polskiej Akademii Umiejętności. Refleksje jubileuszowe Mieczysława Offmańskiego, Tadeusza Sinki, Stanisława Wróblewskiego, Stanistawa Kutrzeby, Kraków 2002, s. 7.

${ }^{50}$ C. Steedman, Przestrzeń pamięci: w archiwum, ,Tytuł Roboczy. Archiwum”2009, nr 2, s. 17. 
powstawały zbiory m.in. Czartoryskich, Ossolińskich, Dzieduszyckich ${ }^{51}$. Zbiory prywatne i spuścizny ${ }^{52}$ nie podlegają obowiązkowi przekazywania ich do archiwów, tak jak w przypadku ustawowo określonych aktotwórców, jednak żadna $\mathrm{z}$ instytucji naukowych czy kulturalnych, takich jak archiwum, biblioteka czy muzeum, nie odmówi sobie przejęcia do swoich zbiorów owych materiałów ${ }^{53}$. Potrzeba zachowywania materiałów wytworzonych przez uczonych oraz wartość tych materiałów w badaniu historii nauki i kultury sprawiły, że istotne miejsce w zasobie sprofilowanych archiwów naukowych, gromadzących w szerokim i różnorodnym zakresie źródła do historii nauki, zaczęły zajmować spuścizny uczonych. Wartość historyczną spuścizn uczonych, czyli archiwów osobistych, w kontekście pamięci, trafnie ujął profesor Jerzy Wyrozumski w słowie wstępnym do publikacji towarzyszącej wystawie Ocalone od niepamięci. Co kryja archiwa osobiste uczonych i twórców. W 10. rocznice powołania Archiwum Nauki PAN i PAU w Krakowie, prezentowanej w Archiwum Nauki od czerwca do października 2012 roku:

Zbiorowa pamięć każdej wspólnoty, stanowiąca fundament jej tożsamości, jest jakąś wypadkową utrwalonych i rozpoznanych pamięci indywidualnych, jednostkowych. Pamięć jednostkowa natomiast - nie ta mglista, właściwa dla tradycji ustnej, ale ukonkretniona i dająca się udokumentować - ma swoje oparcie w spuściznach jednostek, żyje na swój sposób w ich osobistych archiwach. W nich znajdują się zatem przesłanki dla budowania pamięci zbiorowej, którą kreują i utrwalają historycy. Im więcej przesłanek i im wyższa ich jakość, tym bardziej wiarygodne stają się płynące $\mathrm{z}$ nich ogólne wnioski. Uogólniona zaś wiedza - nie można mieć co do tego wątpliwości - stanowi podstawową potrzebę dojrzałych intelektualnie zbiorowości ludzkich. Ona też jest celem dociekań naukowych w zakresie humanistyki ${ }^{54}$.

Spuścizny uczonych do przede wszystkim przedmiot zainteresowań historyków nauki i kultury, ale także wdzięczne pole badawcze dla specjalistów zajmujących się poszczególnymi dyscyplinami nauki. Dostarczają im podstawowego tworzywa do prowadzonych badań i są „nieprzebranym źródłem naukowych imponderabiliów”, będących inspiracją dla uczonych i badaczy. Zgromadzony w Archiwum Nauki materiał spuściznowy stanowi ,podstawową bazę dla badań w zakresie historii nauk, otwierając zarazem przed każdym badaczem perspektywę naukoznawczej refleksji, budującej naukową kulturę o wymiarze interdyscyplinarnym"56.

Gromadzone w Archiwum Nauki PAN i PAU spuścizny uczonych obejmują bardzo szeroki zakres dziedzin - od humanistyki po nauki przyrodnicze i techniczne,

${ }_{51}$ R. Majkowska, Ocalone od niepamięci, pokazane światu.... [w:] Ocalone od niepamięci. Co kryją archiwa osobiste uczonych i twórców? W 10. rocznicę powołania Archiwum Nauki PAN i PAU w Krakowie, Kraków 2012, s. 7; R. Majkowska, Archiwum osobiste, czy spuścizna? [w:] VI Konferencja Archiwów Instytucji Naukowych w Polsce, Kraków 13-14 IX 2001, „Z prac Archiwum UJ”, Kraków 2002, seria F Varia, t. 3, s. 11-21.

${ }^{52}$ Spuścizna - zespół archiwalny wytworzony przez osobę fizyczną.

53 J. Wiśniewski, Archiwalia w bibliotekach i muzeach, Poznań 2000, s. 136.

54 J. Wyrozumski, Słowo wstępne [w:] Ocalone od niepamięci. Co kryją..., s. 5.

55 Tamże, s. 6.

56 Tamże. 
m.in. geologię, historię, prawo, arabistykę, iranistykę, fizykę, turkologię, geografię, zoologię, medycynę, a także biochemię, filozofię, gleboznawstwo, archeologię, matematykę, psychologię. Te zespoły archiwalne, odzwierciedlające kierunki badań i zainteresowań uczonego, zawierają najbardziej zróżnicowane i ciekawe archiwalia, obrazujące warsztat naukowy oraz życie prywatne uczonych i twórców. W tej części zasobu dominują materiały powstałe w XIX i XX wieku, ale pojedyncze sięgają XVII wieku ${ }^{57}$. W gromadzonych spuściznach bardzo często występuje także dokumentacja nieaktowa (inna niż pisana): fotografie, odznaczenia, rysunki, mapy, a także pojedyncze eksponaty muzealne. Spuścizny przekazywane są do Archiwum Nauki w formie daru bądź depozytu, zależnie od dyspozycji właściciela spuścizny lub spadkobierców, rzadko nabywane są przez zakup.

Spuścizny to swoiste źródła historyczne i nośniki pamięci, z których możemy czerpać wiedzę o ludziach minionych epok oraz ich działalności. Archiwum Nauki, gromadząc spuścizny (archiwa osobiste) ludzi nauki i kultury, kreuje pamięć jednostkową (o jednym uczonym) lub pamięci jednostkowe (o kilku uczonych), a jednocześnie pamięć zbiorową. Spuścizna zgromadzona przez uczonego i przekazana do archiwum jeszcze za życia właściciela lub przez spadkobierców po jego śmierci, stanowi szczególnego rodzaju naukowy spadek, mogący służyć (świadomemu lub niekiedy przypadkowemu) kreowaniu siebie jako osoby uczonego lub kreowaniu pamięci o sobie jako uczonym. Spuścizna, czyli archiwum osobiste, jest samoświadectwem jego właściciela - to on bowiem (uczony) nadaje mu pewien konkretny kształt, decydując tym samym, jaką formę ma przyjąć w przyszłości pamięć o nim ${ }^{58}$. Owa autokreacja, czyli tworzenie własnego wizerunku przez uczonego, przejawia się w różny sposób, czego najlepszym świadectwem jest rozmaitość materiałów składających się na daną spuściznę. Spuścizny cechuje dobrowolność (własna inicjatywa gromadzenia materiałów archiwaliów) i dowolność (głównie w doborze materiałów) ${ }^{59}$. Wśród materiałów, które zawiera większość spuścizn gromadzonych w Archiwum Nauki PAN i PAU, wyróżnić można: prace twórcy spuścizny: opracowania, artykuły, referaty, publikacje źródłowe, konspekty i teksty wykładów, recenzje prac, prace popularnonaukowe, przemówienia okolicznościowe, materiały warsztatowe (zapiski, kartoteki, bibliografie, wypisy i notatki z literatury, zapiski obserwacji i badań, obliczenia, odpisy i wypisy archiwalne, fotografie, wycinki prasowe itp.); materiały dzialalności twórcy spuścizny: organizacyjno-naukowej, dydaktycznej, zawodowej, wydawniczej, redakcyjnej; materiały biograficzne: autobiografie, ankiety personalne, zestawienia bibliografii prac własnych, dokumenty osobiste, dokumenty dotyczące przebiegu nauki szkolnej, studiów, pracy i działalności, zeszyty szkolne i notatki ze studiów, pamiętniki, dzienniki i albumy pamiątkowe, dyplomy honorowe, legitymacje odznaczeń, gratulacje i laurki, materiały gospodarcze i majątkowe, materiały dotyczące stanu zdrowia, świadectwo zgonu, klepsydry, zwięzłe nekrologi, kondolencje; korespondencję: wychodząca, wpływająca; materiały o twórcy zespołu:

\footnotetext{
57 T. Skrzyński, Archiwum Nauki..., s. 8-9.

${ }_{58}$ M. Wiśniewska, Archiwum jako miejsce..., s. 141-142.

${ }^{59}$ Tamże, s. 146-147.
} 
życiorysy i wspomnienia, bibliografie prac zestawione przez osoby trzecie, recenzje jego prac, polemiki; materiały rodzinne (rodowe), a nierzadko i materiały osób obcych. Składające się na spuściznę archiwalia udostępniane są zgodnie z prawem archiwalnym, ale z woli ich twórcy bądź spadkobierców niektóre materiały mogą zostać zastrzeżone i być udostępniane po określonym przez nich czasie. Pozostawianie w „uśpieniu” wybranych materiałów i udostępnianie ich w ustalonym momencie przyczynia się do kształtowania określonej i wymaganej w danym czasie pamięci.

Spuścizny ludzi nauki i kultury wykorzystywane przez współczesnych badaczy, są dowodem na to, że nauka w każdym jej obszarze nie zna granic, a pamięć o znanym uczonym i jego dokonaniach istnieje także poza granicami kraju, w którym znajduje się jego spuścizna. Najlepszym tego przykładem jest zgromadzona w Archiwum Nauki spuścizna Władysława Kotwicza (1872-1944), polskiego orientalisty, filologa, specjalizującego się w językach ałtajskich. Ten wybitny uczony i profesor w 1912 roku odbył podróż do Mongolii, w czasie której odwiedził m.in. najstarszy buddyjski klasztor Erdene Dzuu, wzniesiony na gruzach Karakorum, odkrył nieznane inskrypcje mongolskie, przeprowadził wiele badań. Wszystko to utrwalił na zdjęciach i w licznych notatkach będących częścią niezwykłej spuścizny uczonego, przekazanej do archiwum przez córkę Marię Kotwicz. Setna rocznica wyprawy naukowej Władysława Kotwicza do Mongolii, która zbiegła się jednocześnie ze 140-leciem jego urodzin, stała się sprzyjającą okolicznością, aby przypomnieć i uczcić postać zasłużonego dla orientalistyki uczonego. Z tej okazji Polska Akademia Umiejętności i Archiwum Nauki PAN i PAU we współpracy z Wydziałem Orientalistycznym Uniwersytetu Warszawskiego i Komitetem Nauk Orientalistycznych PAN zorganizowały międzynarodową konferencję orientalistyczną Exploring languages and cultures of Asia. Prof. W. Kotwicz In memoriam, poświęconą znakomitemu ałtaiście. Konferencja odbyła się w listopadzie 2012 roku w Polskiej Akademii Umiejętności. Towarzyszyła jej wystawa zatytułowana $W$ sercu Mongolii. Stulecie wyprawy W. Kotwicza do Mongolii w 1912 r., prezentowana w Archiwum Nauki, oraz publikacja In the Heart of Mongolia. 100th Anniversary of W. Kotwicz 's Expedition to Mongolia in 1912. Studies and selected source materials, której autorami są orientaliści z kraju i zagranicy. Te wydarzenia z roku 2012 pokazały, że „,badania Kotwicza i ich baza materiałowa nie poszły w zapomnienie w Polsce, że - co więcej - znalazły oddźwięk w skali międzynarodowej" ${ }^{60}$. Niezwykłą okolicznością stało się również to, że uczeni japońscy pośmiertnie promują polskiego orientalistę, przypominając o jego zasługach i „,wprowadzając do światowego obiegu” tę „część naukowej spuścizny Kotwicza, która dotąd pozostawała w cieniu archiwalnych zasobów" ${ }^{61}$. Setna rocznica ekspedycji Władysława Kotwicza do Mongolii i towarzyszące jej wydarzenia pokazały, że zarówno pamięć, jak i nauka w jej humanistycznym obszarze nie znają granic.

Każdy rodzaj materiału archiwalnego składający się na spuściznę - nośnik pamięci, sam w sobie również jest nośnikiem pamięci. Dla przykładu warto wymienić

60 J. Wyrozumski, Stowo wstępne [w:] W sercu Mongolii. Stulecie wyprawy Władysława Kotwicza do Mongolii w 1912 r. Katalog wystawy, Kraków 2012, s. 4.

${ }^{61}$ Tamże. 
fotografie stanowiące integralną część niemal każdej spuścizny zgromadzonej w Archiwum Nauki. Jako wizualny nośnik pamięci, fotografie współtworzą i dopełniają archiwa osobiste uczonych i twórców zgromadzone w archiwum. Ten specyficzny rodzaj dokumentacji nieaktowej pozwala nam poznać nie tylko postać uczonego, ale też czasy, w których żył, i ludzi, którymi się otaczał ${ }^{62}$. Fotografia to „pożywka dla pamięci, impuls do wzruszeń w kręgach rodzinnych, wierne przywołanie rzeczy i ludzi w każdym wymiarze społecznym, źródło historyczne dla badacza przeszłości [...]"63. Ten drobny urywek czasoprzestrzeni, cieniutka warstwa przestrzeni i czasu ${ }^{64}$, jest najwierniejszym odbiciem jakiegoś fragmentu rzeczywistości uchwyconej na żywo, stwarzającym możliwość doświadczenia tego, co było w przeszłości. Fotografia to źródło historyczne i nośnik pamięci, będący wizualnym zapisem przeszłości, umożliwiającym nam wizualny kontakt z tym, co było, przez zatrzymanie życia w czasie i w formie. Dla uczonego i badacza fotografie stanowią materiał pogłębiający obraz badanej rzeczywistości. Są uzupełnieniem dokumentacji aktowej (pisanej), niekiedy stając się źródłem jedynej informacji historycznej o ludziach minionych epok oraz ich działalności, a mianowicie tzw. fotodokumentem.

W większości spuścizn zgromadzonych w Archiwum Nauki, fotografie najczęściej należą do materiałów biograficznych i rodzinnych twórcy spuścizny. Warto wspomnieć, że w spuściźnie językoznawcy i dialektologa Kazimierza Nitscha (1874-1958) znajdują się pełne uroku dziewiętnastowieczne fotografie, przedstawiające antenatów profesora, jego rodzinę, środowisko naukowe i towarzyskie. Stanowią one interesujący nośnik pamięci o kolejnych etapach życia uczonego, pokazując przy okazji różne formy jego działalności i aktywności na niwie naukowej, społecznej oraz politycznej. Z licznie zgromadzonych w spuściźnie zdjęć można ułożyć nie tylko fotobiografię uczonego, lecz także fragmenty fotograficznej tablicy genealogicznej jego rodziny. Fotografie rodzinne opowiadają historię życia profesora i jego rodziny, stanowiąc doskonałe źródło historyczne, wypełnione po brzegi prywatnymi historiami osób, mających wspólne pochodzenie i przynależących do określonej grupy społecznej. Uchwycona i zatrzymana w obiektywie przemijająca chwila, pieczołowicie przechowywana przez kolejne pokolenia, jest nośnikiem pamięci pozwalającym dziś wywoływać z niebytu świat miniony i ludzi, którzy odeszli. Dla profesora Kazimierza Nitscha fotografie rodzinne były sentymentalną pamiątką jego najbliższych, dla korzystających z jego spuścizny są nośnikiem pamięci, wartym pamięci przy prowadzonych badaniach z zakresu szeroko pojętej kultury, a dla archiwistów - cennym materiałem archiwalnym godnym upamiętnienia. Podczas wystawy pt. Opowieści fotografia pisane. Fotografie $w$ spuściznach uczonych i twórców, prezentowanej w Archiwum Nauki w 2013 roku, zaaranżowano rodzinny kącik fotografii, zbieranych przez profesora Nitscha ${ }^{65}$,

${ }^{62}$ B. Wilk, Wizualny zapis przeszłości. Fotografie w spuściznach jako źródło historyczne, „Archiwista Polski” 2014, R. 19, nr 1, s. 29-44.

${ }_{63}$ J. Wyrozumski, Przedmowa [w:] Opowieści fotografia pisane. Fotografie w spuściznach uczonych i twórców, Kraków 2013, s. 3.

${ }^{64} \mathrm{~S}$. Sontag, O fotografii, http://www.sendspace.pl/file/d5f625788597e0e2874b535/sontagsusan-o-fotografii [odczyt: 10.06.2015].

${ }^{65}$ B. Wilk, Kazimierza Nitscha pamiątka rodzinna [w:] Opowieści fotografia pisane..., s. 24-41. 
w formie drzewa genealogicznego, będący upamiętnieniem tej znanej krakowskiej rodziny. Z kolei na wystawie zatytułowanej Odłamki pamięci o Wielkiej Wojnie. Tym, którym cześć $i$ miłość winniśmy $w$ darze, prezentowanej w Archiwum Nauki w roku 2014, upamiętniono ludzi związanych z nauką, którym przyszło walczyć na frontach I wojny światowej. Wybrane z zasobu archiwalnego „odłamki pamięci” - pozostałości ocalone przed ręką czasu, przypomniały o wojennych czasach, w których przyszło żyć oraz działać wielu uczonym i twórcom, takim jak m.in. Kazimierz Mitera (18971936), artysta plastyk, Zenon Klemensiewicz (1891-1969), językoznawca, Tadeusz Dubiecki (1885-1972), historyk.

Spuścizny jako nośniki pamięci cechuje jedyność i niepowtarzalność.

\begin{abstract}
Nie ma dwóch jednakowych spuścizn uczonych, tak jak nie ma dwóch jednakowych uczonych. Nie chodzi bynajmniej o różnice branżowe, które są oczywiste, ale rzecz w tym, że w jednej i tej samej branży uczeni różnią się niekiedy od siebie diametralnie. [...] Jeżeli to wszystko odzwierciedla się w trafiających do archiwów i bibliotek spuściznach uczonych, jest to okoliczność szczęśliwa. Pokazuje bowiem całe bogactwo ich osobowości ${ }^{66}$.
\end{abstract}

Oznacza to, że tak jak nie ma dwóch jednakowych uczonych i dwóch jednakowych spuścizn, tak samo nie ma dwóch jednakowych pamięci o jednej osobie. Każdą pamięć cechuje indywidualizm i wyjątkowość. Archiwum, posiadając cenne archiwalia jakimi są spuścizny uczonych, doświadczonych archiwistów oraz wykorzystując różne formy działalności w służbie nauki i kultury, stoi na straży pamięci dziedzictwa kulturowego.

\title{
2. Archiwiści jako zarządzający pamięcią
}

Archiwista to zawód wiążący się z działaniami mającymi na celu przechowywanie dokumentów dla ich późniejszego udostępniania. Archiwista to nie tylko pracownik archiwum i znawca archiwaliów, lecz także strażnik pamięci o przeszłości. Charles Kecskeméti napisał, że ,archiwiści są służebnikami narodu, zapewniającymi mu w jakiś sposób ciągłość, że w ich gestii jest bezcenny zbiór informacji o przeszłości, który winien być pomnażany w interesie przyszłych generacji" ${ }^{67}$. Archiwista jest strażnikiem dóbr kultury, biorącym udział w kształtowaniu kultury archiwalnej. Żyjąc w teraźniejszości, żyje z przeszłością, kształtując przyszłe wyobrażenie o teraźniejszości, jest ,zanurzony w czasie" ${ }^{68}$. Archiwista to nie tylko absolwent studiów historycznych ze specjalizacją archiwalną. Archiwista to człowiek o szerokich horyzontach, specjalista od określonej części zasobu archiwalnego, czy też pewnych funkcji archiwalnych. Wreszcie, archiwista to pasjonat i miłośnik przeszłości oraz

${ }^{66}$ J. Wyrozumski, Slowo wstępne [w:] Ocean wszechrzeczy... w spuściznach ludzi nauki i kultury, Kraków 2014, s. 3.

${ }^{67}$ Cyt. za: A. Tomczak, Archiwistyka i zawód archiwisty. Kilka refleksji [w:] Archiwa polskie wobec wyzwań XXI wieku..., s. 28.

${ }^{68}$ A. Tomczak, Archiwistyka i zawód archiwisty..., s. 29. 
pozostałości z dawnych czasów, tj. archiwaliów, czyli nośników pamięci o ludziach i wydarzeniach.

Gromadzone w archiwach materiały archiwalne nie są same w sobie pamięcią, ale z nich należy tę pamięć wydobyć. To zadanie dla archiwistów, którzy najpełniej mogą realizować misję budowania pamięci i przez pamięć - tożsamości, udostępniając i popularyzując archiwalia. Najczęściej dzieje się to poprzez wyjmowanie z zasobu i eksponowanie tych archiwaliów, które służą kształtowaniu określonej lub wymaganej w danym czasie pamięci. Zdeponowane w archiwach zbiory służą do rozważenia relacji między przeszłością a teraźniejszością. W ten sposób archiwa włączają się do budowania pamięci poprzez współpracę z użytkownikiem na polu udostępniania i popularyzacji ${ }^{69}$. Rozpatrując archiwistykę za pomocą kulturowej kategorii pamięci, należy zatem stwierdzić, że archiwista to nie tylko zawód z przeszłością, ale i z przyszłością. Praca archiwistów oznacza bowiem nie tylko porządkowanie materiałów archiwalnych - ,archiwiści to strażnicy pamięci, którzy łączą współczesne pokolenia z historią ich przodków"70.

Zarządzanie pamięcią w archiwistyce to przede wszystkim gromadzenie, zabezpieczanie, opracowywanie, udostępnianie i popularyzacja zasobów archiwalnych oraz prowadzenie działalności informacyjnej. Archiwiści jako zarządzający pamięcią rozumieją potrzebę dokumentowania działalności ludzkiej, propagują idee gromadzenia materiałów archiwalnych jako istoty elementu procesu zachowywania pamięci, popularyzują zasób archiwów. Do tradycyjnych zadań realizowanych przez archiwistów należy przeprowadzanie kwerend archiwalnych, a do nowoczesnych zadań - digitalizacja zasobu archiwalnego. Archiwiści do promocji własnej działalności używają narzędzi właściwych sferze kultury. Prowadzą działalność wydawniczą i ekspozycyjną, opierając się na zgromadzonych materiałach. Zasoby archiwalne to ogromny potencjał edytorski i wystawienniczy, a właściwe nim zarządzanie to budowanie świadomości społecznej oraz więzi międzypokoleniowej. Archiwiści organizują również konferencje naukowe i współpracują z wieloma instytucjami nauki, a także kultury, zwłaszcza z bibliotekami i muzeami. Aktywnie uczestniczą w kształtowaniu wiedzy i świadomości historycznej wśród młodego pokolenia, organizując lekcje i pokazy archiwalne dla studentów kierunków humanistycznych, głównie historii, archiwistyki i bibliotekoznawstwa, przyszłych adeptów sztuki archiwalnej i swoich następców. Archiwiści poprzez różnorodną działalność dbają o zachowanie pamięci o czasach i ludziach minionych epok. Przez udostępnianie i popularyzację różnych archiwaliów, kreują nie tylko pamięć o historii i tradycji, lecz także pamięć o archiwum - miejscu pamięci, w którym pracują, pamięć o archiwaliach - nośnikach pamięci, oraz o samych sobie jako strażnikach pamięci. Praca archiwistów

[...] zaczyna się od prostych czynności, między innymi od wzięcia do ręki materiału. [...] Wykonuje się je bez pośpiechu, koniecznie bez pośpiechu; nigdy dość podkreślania, do jakiego

${ }^{69}$ A. Rosa, Archiwa między historia i pamięcia..., s. 106.

${ }^{70}$ Szef archiwów w Polsce: archiwiści to strażnicy pamięci. Rozmowa Norberta Nowotnika (PAP) z Naczelnym Dyrektorem Archiwów Państwowych profesorem Władysławem Stepniakiem, http:// dzieje.pl/aktualnosci/szef-archiwow-w-polsce-archiwisci-straznicy-pamieci [odczyt: 10.06.2015]. 
stopnia praca w archiwum jest powolna i jak bardzo ta powolność rąk i umysłu może być twórcza. Bardziej nawet niż twórcza jest ona nieunikniona: sterty dokumentów są nieustannie czytane po kolei; nawet jeśli ich liczba jest ograniczona i dokładnie oszacowana przez wcześniejsze badanie, wymagają od czytelnika ogromnej cierpliwości ${ }^{71}$.

Znając i rozumiejąc zarówno podobieństwa, jak i różnice wynikające z organizacji i funkcjonowania archiwów, bibliotek, muzeów i ośrodków dokumentacyjnych, archiwiści są otwarci na współpracę wszystkich instytucji pamięci ${ }^{72}$.

Istnienie Archiwum Nauki PAN i PAU na mapie kulturalnej Krakowa stanowi oparcie dla rozwoju życia naukowo-kulturalnego miasta i oddziałuje na poziom szerokiego grona odbiorców. Świadomość społeczeństwa, że w Archiwum Nauki zgromadzone są spuścizny świadczące o życiu i działalności uczonych polskich, ma duże znaczenie. Przed historykami i archiwistami pracującymi w tej instytucji stoi wiele zadań, aby dotrzeć do jak najszerszego kręgu odbiorców. Archiwiści gromadzone w Archiwum spuścizny opracowują zgodnie z wytycznymi opracowania spuścizn archiwalnych po uczonych, tworząc różnego rodzaju pomoce archiwalne służące korzystającym z zasobu. Przeprowadzają kwerendy dla osób zainteresowanych i udostępniają korzystającym materiały archiwalne w pracowni naukowej. $\mathrm{W}$ trosce o właściwe zabezpieczenie materiałów szczególnie cenne archiwalia poddają konserwacji.

Popularyzacja zasobu archiwalnego odbywa się poprzez działalność wystawienniczą. W roku 1996 Archiwum zainicjowało cykl wystaw $W$ stużbie nauki..., poświęconych uczonym polskim. Odtąd cyklicznie, dwa razy w roku, archiwiści przygotowywali wystawę dedykowaną jednemu uczonemu, którego spuścizna znajduje się w zbiorach archiwum. Każdej z wystaw towarzyszył katalog wystawy, a także posiedzenie naukowe zorganizowane w Polskiej Akademii Umiejętności z referatami o życiu i działalności uczonego, a jego pokłosie stanowiła seria wydawnicza o tym samym tytule. Do 2012 roku, najczęściej z okazji przypadającej rocznicy urodzin lub śmierci uczonego, zaprezentowano w tym cyklu 28 wystaw biograficznych, których bohaterami byli przedstawiciele różnych dyscyplin nauki: historycy, prawnicy, filozofowie, językoznawcy, fizycy, matematycy, a także przyrodnicy ${ }^{73}$. Przygotowując wystawę, archiwiści zarządzają pamięcią o uczonym poprzez wybór materiałów do zaprezentowania na ekspozycji. Najczęściej „wyjmują” z zasobu archiwum te materiały, które mają posłużyć do przedstawienia człowieka i uczonego w kontekście jego działalności, według opracowanego scenariusza wystawy, inne materiały pozostawiając w ,uśpieniu”. Przyczyniają się tym samym do kształtowania określonej w danym czasie pamięci. Niewielka sala wystawowa archiwum niemal wymusza na autorach wystaw dokonanie selekcji i wydobycie z zasobów spuściznowych

71 A. Farge, Gesty gromadzenia, „Tytuł Roboczy. Archiwum” 2009, nr 2, s. 13.

${ }_{72}$ Model kompetencji zawodowych archiwistów i zarządców dokumentacji. Rekomendacja Zarządu Glównego Stowarzyszenia Archiwistów Polskich uchwalona 4 listopada 2010 roku, http://sap. waw.pl/dzialalnosc_statutowa/model-kompetencji-zawodowych-archiwisty [odczyt: 10.06.2015].

${ }^{73} \mathrm{~W}$ stużbie nauki, http://www.archiwum-nauki.krakow.pl/pl/wystawy/lista-wystaw.html [odczyt: 10.06.2015]. 
najatrakcyjniejszych i najciekawszych archiwaliów w celu przedstawienia nie tylko warsztatu naukowego, lecz także życia osobistego oraz działalności pozanaukowej uczonego i badacza. Przez wystawy w cyklu $W$ stużbie nauki archiwiści przypominają niekiedy zapomniane postacie zasłużonych dla polskiej nauki i kultury uczonych oraz twórców. Posiedzenia naukowe, na których referaty wygłaszają i dyskutują często byli uczniowie profesora, któremu poświęcona jest wystawa, są okazją do wspomnień i przypominania ważnych w nauce, teraz często zaniedbywanych relacji mistrz-uczeń. Publikacja będąca pokłosiem tych wydarzeń, dzięki opublikowanym referatom oraz różnorodnym ilustracjom, dokumentuje i pogłębia wiedzę o uczonym, stając się jednocześnie kolejnym nośnikiem pamięci o nim. Popularyzacja zasobu archiwalnego przez organizowanie wystaw, będąca jednocześnie jedną z form zarządzania pamięcią o ludziach nauki i kultury, wynika z poszanowania materiałów, zarówno tych spuściznowych, jak i z wkładu uczonego w rozwój nauki, a także ze świadomości zaszczepiania kultury archiwalnej i kształtowania kultury pamięci wśród zwiedzających.

Archiwum Nauki realizuje również niewielkie ekspozycje w formie planszowej w Pałacu Kultury i Nauki w Warszawie, prezentujące bogactwo zasobu archiwalnego na przykładzie archiwaliów pochodzących ze spuścizn uczonych, a także ekspozycje okolicznościowe, związane często $\mathrm{z}$ ważniejszymi wydarzeniami w krakowskim świecie nauki i kultury. Misja popularyzowania spuścizn uczonych realizowana jest także poprzez pokazy archiwalne dla studentów historii i archiwistyki krakowskich uczelni. Od roku 2007 Archiwum Nauki organizuje konferencje poświęcone archiwom naukowym oraz problematyce spuścizn gromadzonych w archiwach, bibliotekach i muzeach. Współpracuje z archiwami krajowymi i zagranicznymi oraz instytucjami o podobnym profilu naukowym. Szczególnie warto podkreślić współpracę z Archiwum Akademii Nauk Czeskiej Republiki oraz Archiwum Uniwersytetu Karola w Pradze. Pracownicy Archiwum Nauki biorą udział w pracach redakcyjnych serii wydawniczej W Służbie Nauki, publikują artykuły, katalogi i foldery wystaw oraz wygłaszają referaty, dzieląc się pamięcią o uczonych i badaczach, których spuściznami zarządzają.

Dążąc do jak najszerszego udostępnienia informacji o spuściznach, Archiwum Nauki razem z Archiwum Narodowym w Krakowie, Archiwum Uniwersytetu Jagiellońskiego, Archiwum Uniwersytetu Papieskiego Jana Pawła II, Biblioteką Jagiellońską, Biblioteką Naukową PAU i PAN oraz Muzeum Archeologicznym w Krakowie realizuje inicjatywę stworzenia wspólnej informacji o rozproszonych materiałach spuścizn ludzi nauki i kultury w formie bazy danych Spuścizna. Archiwa, biblioteki, muzea krakowskie (www.spuscizna.krakow.pl/\#). Zgromadzona w ciągu życia spuścizna często z wielu powodów ulega rozproszeniu. Składa się na to wiele czynników, m.in. praca w kilku instytucjach, co powoduje, że materiały pozostają w wielu miejscach. Po śmierci twórcy skomplikowane bywają losy spuścizny, dzielonej i przekazywanej przez spadkobierców do różnych zbiorów archiwalnych, bibliotecznych lub muzealnych. Taka dowolność w dysponowaniu archiwami osobistymi powoduje rozproszenie cennych dla poznania historii nauki i kultury zbiorów oraz utrudnienia w prowadzonych badaniach i dostępie do informacji. Archiwiści, bibliotekarze 
i muzealnicy mają świadomość, że materiały znajdujące się w ich zbiorach nie stanowią całości spuścizny danego uczonego lub twórcy, a tym samym, że pamięć, którą gromadzą, udostępniają i popularyzują, nie jest pełna. Z tego powodu Archiwum Nauki wspólnie z innymi instytucjami podjęło inicjatywę scalenia informacji o spuściznach, a tym samym o pamięci po ludziach nauki i kultury. To przedsięwzięcie świadczy, że pamięć zbiorowa o uczonych jest rozdzielona, a zadaniem archiwistów jako zarządzających spuściznami i pamięcią jest współpraca na tym polu z innymi archiwistami, bibliotekarzami i muzealnikami, którzy pracując w miejscach pamięci, zarządzają nośnikami pamięci - dobrami nauki i kultury.

\section{Zakończenie}

Dla każdej epoki i dla każdego pokolenia ważne jest pozostawienie po sobie śladu - zapisu działalności, myśli i uczuć, stanowiącego jedną z form komunikowania międzypokoleniowego i międzyepokowego. Jednym z miejsc, gdzie są przechowywane owe ślady, świadectwa przeszłości, są archiwa - miejsca pamięci. Archiwa od wieków stanowią element kultury w jej ogólnoświatowym wymiarze. Dla współczesnych społeczeństw i narodów są podstawowym narzędziem ochrony dziedzictwa i kształtowania własnej kultury pamięci. Gromadzone tam materiały - archiwalia są nośnikami pamięci, stanowiącymi dobra kultury narodowej, z których mogą korzystać współcześni oraz przyszli uczeni i badacze. Pracujący w archiwach archiwiści są strażnikami pamięci narodowej.

Omówione na przykładzie Archiwum Nauki PAN i PAU zagadnienie archiwum jako miejsca pamięci o uczonym wzbogaciło dotychczasową wiedzę nie tylko na ten temat, ale w ogóle - o archiwach jako miejscach pamięci, archiwaliach jako nośnikach pamięci i archiwistach jako zarządzających tą pamięcią. Kwestie tutaj omówione mogą dla historyków kultury i badaczy pamięci stanowić wdzięczne pole do dalszych szczegółowych studiów.

\section{Bibliografia}

\section{Opracowania:}

Didier J., Słownik filozofii, Kraków 1992.

Goff J. Le, Historia i pamięć, tłum. A. Gronowska, J. Stryjczyk, Warszawa 2007.

Halbwachs M., Społeczne ramy pamięci, thum. M. Król, Warszawa 1969.

Hübner P., Od Towarzystwa Naukowego Krakowskiego do Polskiej Akademii Umiejętności. Refleksje jubileuszowe Mieczysława Offmańskiego, Tadeusza Sinki, Stanisława Wróblewskiego, Stanisława Kutrzeby, Kraków 2002.

Kostro R., Wprowadzenie [w:] Węzty pamięci niepodległej Polski, red. Z. Najder, A. Machcewicz, M. Kopczyński i in., Kraków-Warszawa 2014.

Majkowska R., Archiwum Nauki - idea i rzeczywistość [w:] Archiwa polskie wobec wyzwań XXI wieku. Pamiętnik III Powszechnego Zjazdu Archiwistów Polskich, Toruń 2-4 września 1997, Warszawa 1998, t. II, s. 177-185. 
Majkowska R., Archiwum osobiste, czy spuścizna? [w:] VI Konferencja Archiwów Instytucji Naukowych w Polsce, Kraków 13-14 IX 2001, „Z prac Archiwum UJ”, seria F Varia, t. 3, Kraków 2002, s. 11-21.

Majkowska R., Ocalone od niepamięci, pokazane światu... [w:] Ocalone od niepamięci. Co kryja archiwa osobiste uczonych i twórców? W 10. rocznice powołania Archiwum Nauki PAN i PAU w Krakowie, Kraków 2012, s. 7-14.

Pamięć dla przyszłości, Z. Stachowski (red.), Tyczyn 2002.

Pamięć zbiorowa i kulturowa. Współczesna perspektywa niemiecka, M. Saryusz-Wolska (red.), Kraków 2009.

Polski stownik archiwalny, W. Maciejewska (red.), Warszawa 1974.

Pomian K., Historia - nauka wobec pamięci, Lublin 2006.

Ricoeur P., Pamięć, historia, zapomnienie, tłum. J. Margański, Kraków 2007.

Rothberg M., Multidirectional memory. Remembering the Holocaust in the age of decolonization, Stanford 2009.

Skrzyński T., Archiwum Nauki Polskiej Akademii Nauk i Polskiej Akademii Umiejętności. Z przeszłości i teraźniejszości, Kraków 2008, broszura.

Szacka B., Czas przeszty, pamięć, mit, Warszawa 2006.

Tomczak A., Archiwistyka i zawód archiwisty. Kilka refleksji [w:] D. Nałęcz (red.), Archiwa polskie wobec wyzwań XXI wieku. Pamiętnik III Powszechnego Zjazdu Archiwistów Polskich, Toruń 2-4 września 1997, t. 1, Radom 1997, s. 23-30.

Wilk B., Kazimierza Nitscha pamiątka rodzinna [w:] Opowieści fotografia pisane. Fotografie w spuściznach uczonych i twórców, red. M. Włodek, Kraków 2013, s. 24-41.

Wiśniewski J., Archiwalia w bibliotekach i muzeach, Poznań 2000.

Wobec przeszłości. Pamięć przeszłości jako element kultury współczesnej, A. Szpociński (red.), Warszawa 2005.

Wyrozumski J., Przedmowa [w:] Opowieści fotografia pisane. Fotografie w spuściznach uczonych i twórców, M. Włodek (red.), Kraków 2013, s. 3-4.

Wyrozumski J., Stowo wstępne [w:] Ocalone od niepamięci. Co kryją archiwa osobiste uczonych i twórców? W 10. rocznice powołania Archiwum Nauki PAN i PAU w Krakowie, Kraków 2012, s. 4-6.

Wyrozumski J., Stowo wstępne [w:] M. Maciuk, Ocean wszechrzeczy... w spuściznach ludzi nauki i kultury, Kraków 2014, s. 3-5.

Wyrozumski J., Stowo wstepne [w:] W sercu Mongolii. Stulecie wyprawy Władysława Kotwicza do Mongolii w 1912 r. Katalog wystawy, Kraków 2012, s. 3-4.

Zatroskani o ślady przeszłości. Archiwista kościelny we wspótczesnej rzeczywistości, J. Marecki, L. Rotter (red.), Kraków 2005.

\section{Artykuły:}

Bieńkowska E., Mała historia pamięci. Pamięć jednostkowa, pamięć zbiorowa, „Znak” 1995, R. 47, nr 480, s. 19-30.

Chorążyczewski W., Archiwa i pamięć. Nowa interpretacja archiwistyki (na marginesie XV Kongresu Archiwów w Wiedniu), „Archiwista Polski” 2004, R. 9, nr 4, s. 9-13.

Chorążyczewski W., Archiwa i pamięć. Z dziejów polskich archiwów, „Archiwa - Kancelarie Zbiory” 2005, t. 1, s. 13-28.

Dziurzyńska E., Powstanie Archiwum Nauki Polskiej Akademii Nauk i Polskiej Akademii Umiejętności w Krakowie, „Krakowski Rocznik Archiwalny” 2003, t. 9, s. 285-288.

Farge A., Gesty gromadzenia, „Tytuł Roboczy. Archiwum” 2009, nr 2, s. 13-15.

Gabryś A., O badaniu pamięci, „Historyka. Studia metodologiczne” 2005, t. 35, s. 135-149.

Jerochina J.A., Pamięć i wiedza o przeszłości jako formy bytowania świadomości historycznej, „Sensus Historiae” 2013, vol. 11, nr 2, s. 63-70. 
Kędziora A., Miejsca pamięci w zarządzaniu pamięcia o artyście, „Zarządzanie w Kulturze” 2012, t. 13 , nr 2, s. 101-111.

Kędziora A., Zarządzanie pamięcia o artyście na przyktadzie szlaku kulturowego, „Problemy Zarządzania” 2013, vol. 11, nr 4, s. 101-112.

Klaś J., Muzea historyczne - pomiędzy pamięcia zbiorowa a polityka pamięci historycznej, „Zarządzanie w Kulturze" 2013, t. 14, z. 3, s. 197-215.

Korzeniowski B., O sposobach obchodzenia się z reliktami przeszłości, „Sensus Historiae” 2012, vol. 6, nr 1, s. 35-47.

Kurkowska M., Archiwa pamięci - oral history, „Historyka. Studia metodologiczne” 1998, t. 28, s. $67-76$.

Majchrzak K., Od miejsc pamięci narodowej do miejsc żywej pamięci-implikacje dla andragogi$k i$, ,Rocznik Andragogiczny” 2013, R. 20, s. 301-311.

Majkowska R., Archiwum Polskiej Akademii Umiejętności - dzieje, zasób, stan opracowania, „Krakowski Rocznik Archiwalny” 1996, t. 2, s. 70-84.

Napiórkowski M., Prawda archiwów, „Kultura Współczesna” 2011, nr 4, s. 12-26.

Nora P., Between Memory and History: Les Lieux de Mémoire, „Representations” 1989, nr 26, Special Issue: Memory and Counter-Memory, s. 7-24.

Nora P., Czas pamięci, „Res Publica Nowa” 2001, R. 14, nr 7, s. 37-43.

Nora P., Między pamięcia a historią: Les lieux de Mémoire, „Tytuł Roboczy. Archiwum” 2009, nr 2, s. 4-12.

Polasik-Wrzosek K., Pamięć kulturowa a historiografia jako zapis kultury. Konteksty do zbadania, „Historyka. Studia metodologiczne” 2011, t. 41, s. 137-144.

Rosa A., Archiwa między historia i pamięcia. Antropologizowanie archiwistyki, „Archiwa - Kancelarie - Zbiory" 2008, t. 2, s. 99-127.

Skrzyński T., Archiwum Nauki Polskiej Akademii Nauk i Polskiej Akademii Umiejętności. Z przeszłości i teraźniejszości, „Archiwista Polski” 2004, R. 9, nr 1, s. 17-23.

Steedman C., Przestrzeń pamięci: w archiwum, „Tytuł Roboczy. Archiwum” 2009, nr 2, s. 16-23.

Stępniak W., Archiwa - państwo - naród. Dwieście lat na straży pamięci narodowej, „Archiwista Polski” 2008, R. 13, nr 4, s. 21-25.

Szacka B., O pamięci społecznej, „Znak” 1995, R. 47, nr 480, s. 68-76.

Szpociński A., Miejsca pamięci (lieux de mémoire), „Teksty Drugie” 2008, nr 4, s. 11--20.

Szpociński A., „Miejsca pamięci” w ujęciu Pierre'a Nory, „Borussia. Kultura, Literatura, Historia" 2003, R. 13, nr 29, s. 16-27.

Szpociński A., Nośniki pamięci, miejsca pamięci, „Sensus Historiae” 2014, vol. 17, nr 4, s. 17-26.

Wilk B., Wizualny zapis przeszłości. Fotografie w spuściznach jako źródło historyczne „Archiwista Polski” 2014, R. 19, nr 1, s. 29-44.

Wiśniewska M., Archiwum jako miejsce pamięci, „Archiwa - Kancelarie - Zbiory” 2013, nr 4, s. $137-148$.

Zagrożenie archiwów - skarbnicy pamięci państwa i narodu, „Archeion” 1996, t. 96, s. 62-75.

\section{Dokumenty elektroniczne:}

Filip T., Od archiwum dwóch Akademii do Archiwum Nauki, http://archiwum.amu.edu.pl/publikacje/15.pdf [odczyt: 10.06.2015].

Filipowicz J., Pojęcie pamięci społecznej w nauce polskiej, „Kultura i Historia” 2002, nr 2, http:// www.kulturaihistoria.umcs.lublin.pl/archives/145 [odczyt: 10.06.2015]

Hlebionek M., O pamięci historycznej, http://wirtualnemuzeumtrzcianki.trz.pl/sites/default/files/ Pamięć4.pdf [odczyt: 10.06.2015].

Kuryła M., O Instytucie „Pamięci Narodowej”, czyli Polaków problemy z pamięcia oraz historia, http://www.mojeopinie.pl/o_instytucie_pamieci_narodowej_czyli_polakow_problemy_z_ pamiecia_oraz_historia,3,1397075661 [odczyt: 10.06.2015]. 
Model kompetencji zawodowych archiwistów i zarzadców dokumentacji. Rekomendacja Zarzadu Gtównego Stowarzyszenia Archiwistów Polskich uchwalona 4 listopada 2010 roku, http:// sap.waw.pl/dzialalnosc_statutowa/model-kompetencji-zawodowych-archiwisty[odczyt:10.06. 2015].

Mróz M.W., Archiwum jako instytucja kultury historycznej, http://archiwum.amu.edu.pl/publikacje/2.pdf [odczyt: 10.06.2015].

Pazderski F., Czemu przeszłość się pamięta - wokół dyskusji na temat ksztattowania się pamięci zbiorowej, http://www.drumla.org.pl/czytelnia.html [odczyt: 10.06.2015].

Pojęcia dotyczace pamięci oraz miejsc pamięci, http://dipp.info.pl/index.php/2013-02-06-09-2703/87-troche-teorii [odczyt: 10.06.2015].

Sontag Susan, O fotografii, http://www.sendspace.pl/file/d5f625788597e0e2874b535/sontag-susan-o-fotografii [odczyt: 10.06.2015].

Szef archiwów w Polsce: archiwiści to strażnicy pamięci. Rozmowa Norberta Nowotnika (PAP) z Naczelnym Dyrektorem Archiwów Państwowych profesorem Władysławem Stęniakiem, http://dzieje.pl/aktualnosci/szef-archiwow-w-polsce-archiwisci-straznicy-pamieci [odczyt: 10.06.2015].

W slużbie nauki, http://www.archiwum-nauki.krakow.pl/pl/wystawy/lista-wystaw.html [odczyt: 10.06.2015].

Wóycicki K., Zagadnienie historiografii pamięci, https://kazwoy.wordpress.com/mojepublikacje/ zagadnienie-historiografii-pamieci/ [odczyt: 10.06.2015]. 